\title{
Molecular detection of Ehrlichia canis in ticks population collected on dogs in Meshkin-Shahr, Ardebil Province, Iran
}

\author{
Atefeh Khazeni ${ }^{1}$, Zakieh Telmadarraiy ${ }^{1 *}$, Mohammad Ali Oshaghi ${ }^{1}$, Mehdi Mohebali ${ }^{2}$, \\ Zabiholah Zarei $^{2}$, Seyed Mohammad Abtahi ${ }^{3}$ \\ ${ }^{1}$ Department of Medical Entomology and Vector Control, School of Public Health, Tehran University of Medical Sciences (TUMS), \\ Tehran, Iran \\ ${ }^{2}$ Department of Medical Parasitology, School of Public Health, Tehran University of Medical Sciences (TUMS), Tehran, Iran \\ ${ }^{3}$ Department of Parasitology, School of Medicine, Isfahan University of Medical Sciences and Health Services, Isfahan, Iran \\ Email: *telmadarraiy@tums.ac.ir, khazeniat@yahoo.com
}

Received 24 April 2013; revised 26 May 2013; accepted 18 June 2013

Copyright (C) 2013 Atefeh Khazeni et al. This is an open access article distributed under the Creative Commons Attribution License, which permits unrestricted use, distribution, and reproduction in any medium, provided the original work is properly cited.

\begin{abstract}
Canine monocytic ehrlichiosis is a disease which can cause death in dogs and cats by the Ehrlichia canis and transmitted by hard ticks. The main vector is Rhipicephalus sanguineus which is a common tick in Iran and common ectoparasite on dogs. Few researches has been done to show Ehrlichiosis situation in dog's ticks. Animal husbandry in Meshkin-Shahr County from Ardebil province (North-West Iran) is the main job of people. Specimens were collected on dogs' ears, neck, shoulder and toes and they were transferred to the Entomology Laboratory, School of Public Health, Tehran University of Medical Sciences. After DNA extraction, Ehrlichia agent was detected by nested-PCR, 16 s rRNA amplification. Determination of sequence homologies have been done in Gen-Bank. 146 ticks were identified which included $29.44 \%$ female and $47.94 \%$ male. $R$ hipicephalus sanguineus were the most prevalent ticks. Ehrlichia spp and Anaplasma spp were found in $43.84 \%$ of all the specimens containing Anaplasma ovis, and Ehrlichia sp. and Herlichia canis. Rhipicephalus sanguineus is widely spread and the most common ticks on dogs. As far as we know, this is the first report of $E$. canis in vector from Iran. Nested PCR showed that hard ticks can contain Anaplasma ovis, Ehrlichia spp and E. canis. These results warrant studying on vector competence of ticks for the Ehrlichiosis agents.
\end{abstract}

Keywords: Ehrlichiosis; Tick; Dog; Anaplasma ovis; Ehrlichia canis; Ardebil; Iran

${ }^{*}$ Corresponding author.

\section{INTRODUCTION}

Tick-borne pathogens lead to over 100,000 cases of illness in the world each year [1]. Ehrlichia chaffeensis, E. canis, E. ewingii, and Anaplasma phagocytophilum are the most significant tick-borne pathogens of human and animals belong to the family Anaplasmataceae. Ehrlichiosis is a worldwide zoonosis illness, mostly occurs in tropical and subtropical regions that are close to the vector's distribution $[2,3]$.

Canine monocytic ehrlichiosis (CME) is a tick-borne disease which can cause death in dogs and cats by the Ehrlichia canis, that is an obligate intracellular bacteria [1]. The main vector is Brown dog tick, Rhipicephalus sanguineus [4]. This tick can transmit E. canis, 155 days after infection and act as a strong reservoir; they can transmit the pathogen transtadially [5,6]. Rhipicephalus sanguineus has been reported as a vector of Ehrlichia canis, Babesia canis and Borrelia burgdorferi. During the attachments on the host, they transmit the infection to host via salivation and regurgitation at the attachment site $[7,8]$.

Rhipicephalus sanguineus is a common tick in Iran and its common hosts are domestic dogs [9]. Tick lives on dogs for all stages of development. They can also attach to the small animals like rodents, cattle and humans $[3,10]$. Adults are found mainly on the dogs' ears, along the neck and shoulder and between the toes. Nymphs are usually found on ears and long haired areas of the neck [11].

Despite of studies that have been done on ticks infestation and tick-borne diseases in Iran recently, few researches have been done to assess the situation of Ehr- 
lichiosis in dog ticks. The first report of Anaplasma phagocytophilum in Iran has showed that 5.1\% of Ixodes ricinus population had been infected by this Rickettsia [12]. Also, in Ahvaz, 20.83\% of dogs with thrombocytopenic and $8.05 \%$ of dogs without thrombocytopenic had been positive for ehrlichiosis [13].

\section{MATERIALS AND METHODS}

Study area: This study was conducted in MeshkinShahr County from Ardebil province (North-West Iran) with 38 degrees North latitude and 47 degrees Eastern longitude. Approximately 70,000 people live in this county and animal husbandry is the occupation of most people.

Samples collection: From December 2011 to December 2012, 36 dogs in Meshkin-Shahr (Figure 1) were selected for this study. Ticks were mostly found on ears, neck, shoulder and toes. Specimens were collected from dogs using a forceps, in this part should be careful not to damage the tick body otherwise it will be difficult to morphological identification, then transferred into the labeled holding tubes individually. In some cases it was impossible to collect all ticks due to lack of time or dog's behavior.

Specimens were transferred to the Entomology Laboratory, School of Public Health, Tehran University of Medical Sciences. All specimens were identified based on morphological characteristics and the keys given by Janbakhsh and Walker based on shape of capitulum, scutum, eyes, festoone and hypostome $[14,15]$.

DNA extraction: DNA was extracted using the G$\operatorname{spin}^{\mathrm{TM}}$ Genomic DNA Extraction kit (iNtRON). Extraction was carried out according to the manufacturer instructions by grinding of individual ticks in an eppendorf microtube after maintaining 5 minutes in the liquid nitrogen tank and using glass pestle. $400 \mu \mathrm{l}$ of G-buffer per $20-30 \mathrm{mg}$ of tissue was added and incubated at $70^{\circ} \mathrm{C}$ for 5 - $10 \mathrm{~min}$ (for much tissue increased incubation time) then mixed well $2-3$ times. $400 \mu$ of Binding buffer was added and transferred to the G-spine columns in the next step, centrifuged for $1 \mathrm{~min}$ at $13,000 \mathrm{rpm}$. In the subsequent process, $500 \mu \mathrm{l}$ of washing buffer and $200 \mu \mathrm{l}$

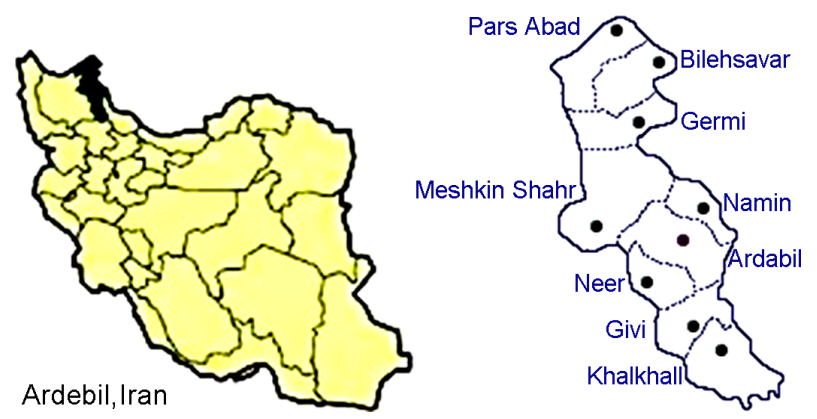

Figure 1. Geographical location of Ardebil province and Meshkin-Shahr county, Iran. of elution buffer were added respectively and centrifuged for $1 \mathrm{~min}$ at 13,000 rpm. After adding elution buffer, samples were incubated for $1 \mathrm{~min}$ at room temperature. Samples could store at $4^{\circ} \mathrm{C}$.

Detection of Ehrlichia spp. by Nested-PCR: Using primers (Table 1) detection of Ehrlichia was performed by nested-PCR, $16 \mathrm{~s}$ rRNA amplification, [16]. PCR amplifications were done in a Maxime PCR premix kit (iTaq). For primary reactions $5 \mu \mathrm{l}$ of purified DNA was used as a template in mentioned PCR premix kit. The PCR cycles were consist of 5 minutes at $94^{\circ} \mathrm{C}, 35$ cycles of $94^{\circ} \mathrm{C}$ for 1 minute (denaturation of DNA), $60^{\circ} \mathrm{C}$ for 1 minutes (annealing of primers), $72^{\circ} \mathrm{C}$ for 1 minutes (extension of the primers), and a final extension at $72^{\circ} \mathrm{C}$ for 7 minutes. Nested-PCR assay was performed using species-specific primers (Ehr 3, Ehr 4) (Table 1) [17] and 3.0 $\mu \mathrm{L}$ from the initial PCR was used as a template. The PCR products were visualized on a $1 \%$ agarose gel, stained with ethidium bromide and UV light in TBE buffer $(0.09 \mathrm{mM}$ Tris, $0.09 \mathrm{mM}$ boric acidand $20 \mathrm{mM}$ EDTA, $\mathrm{pH}$ 8.3).

Nucleotide sequencing: Sequencing was performed using an ABI 3730 sequencer machine. Obtained sequences were checked to correct ambiguities. Determination of sequence homologies have been done in GenBank by BlastN and aligned with ClustalW was checked using basic local alignment search tool (BLAST) analysis software (www.ncbi.nlm.nih.gov/BLAST).

\section{RESULT}

Tick Species: A total of 146 collected ticks were morphologically identified to the species level. They included two Rhipicephalus, three Hyalomma, two Dermacentor and one Ornithodoros species (the species of ticks have been shown in Table 2).

As expected, Rhipicephalus sanguineus with $32.19 \%$ were the most prevalent ticks on dogs in the mentioned area and the number of males was higher than females; the sex ratio (number of males/females * 100) was 144 . $10 \%$. In the second ranking, after Rhipicephalus sanguineus specimens, Rhipicephalus bursa was the most

Table 1. Details of the primers were used for Ehrlichia spp. and Anaplasma spp. detection in ticks collected on dogs, Ardebil Province, Iran, 2012.

\begin{tabular}{|c|c|c|}
\hline \multirow{2}{*}{$\begin{array}{c}\text { Nested-PCR } \\
1\end{array}$} & $\begin{array}{l}\text { 5'-GAACGAACGCTGGCGGCAA- } \\
\text { GC-3' }\end{array}$ & $\begin{array}{c}\text { Ehr } 1 \text { (Forward } \\
\text { Primer) }\end{array}$ \\
\hline & $\begin{array}{l}\text { 5'-AGTA[T/C }] \mathrm{CG}[\mathrm{A} / \mathrm{G}] \mathrm{ACCAGATA}- \\
\text { GCCGC-3' }\end{array}$ & $\begin{array}{l}\text { Her } 2 \text { (Reverse } \\
\text { Primer) }\end{array}$ \\
\hline \multirow{2}{*}{$\begin{array}{l}\text { Nested-PCR } \\
\quad 2\end{array}$} & $\begin{array}{c}\text { 5'-TGCATAGGAATCTACCTAGT- } \\
\text { AG-3' }\end{array}$ & $\begin{array}{c}\text { Her } 3 \text { (Forward } \\
\text { Primer) }\end{array}$ \\
\hline & $\begin{array}{l}\text { 5'-CTAGGAATTCCGCTATCCT- } \\
\text { CT-3' }\end{array}$ & $\begin{array}{l}\text { Her } 4 \text { (Reverse } \\
\text { Primer) }\end{array}$ \\
\hline
\end{tabular}


Table 2. Details of tick specimens were PCR positive against Ehrlichia spp. and Anaplasma spp.

\begin{tabular}{ccccc}
\hline Species & No. & $\begin{array}{c}\text { \% Species } \\
\text { in } \\
\text { Collected } \\
\text { Specimens }\end{array}$ & $\begin{array}{c}\text { Positive } \\
\text { Ehrlichia spp. } \\
\text { \& Anaplasma } \\
\text { spp. }\end{array}$ & $\begin{array}{c}\text { \% Positive } \\
\text { Ehrlichia spp. } \\
\text { \& Anaplasma } \\
\text { spp. }\end{array}$ \\
\hline $\begin{array}{c}\text { Rhipicephalus } \\
\text { sanguineus }\end{array}$ & 47 & 32.19 & 30 & 63.82 \\
$\begin{array}{c}\text { Rhipicephalus } \\
\text { bursa }\end{array}$ & 23 & 15.75 & 12 & 52.17 \\
$\begin{array}{c}\text { Hyalomma } \\
\text { asiaticum }\end{array}$ & 20 & 13.69 & 9 & 45 \\
$\begin{array}{c}\text { Hyalomma } \\
\text { marginatum }\end{array}$ & 16 & 10.95 & 0 & 0 \\
$\begin{array}{c}\text { Hyalomma } \\
\text { anatolicum }\end{array}$ & 6 & 4.1 & 4 & 66.66 \\
$\begin{array}{c}\text { Dermacentor } \\
\text { niveus }\end{array}$ & 3 & 2.05 & 0 & 0 \\
$\begin{array}{c}\text { Dermacentor } \\
\text { marginatus }\end{array}$ & 15 & 10.27 & 9 & $\mathbf{4 3 . 8 3}$ \\
$\begin{array}{c}\text { Ornithodoros } \\
\text { lahorensis }\end{array}$ & 16 & 10.95 & 0 & $\mathbf{6 4}$ \\
\begin{tabular}{c} 
Total \\
\hline
\end{tabular} & $\mathbf{1 4 6}$ & $\mathbf{1 0 0}$ & $\mathbf{6 4}$ & \\
\hline
\end{tabular}

prevalent tick with $15.75 \%$ which $7.57 \%$ of them were nymphs.

On total, $43(29.44 \%)$ out of all 146 specimens were female and $70(47.94 \%)$ were male; the remaining $22.62 \%$ were held by the nymphs; however, the ratio ofDermacentor niveus specimens was significantly much lower $(2.05 \%)$ than that of the other.

Ehrlichia and Anaplasma Detection: 146 specimens, including 47 Rhipicephalus sanguineus, 23 Rhipicephalus bursa, 20 Hyalomma asiaticum, 16 Hyalomma marginatum, 3 Dermacentor niveus, 6 Hyalomma anatolicu and 15 Dermacentor marginatus were tested for the presence of ehrlichial's DNA. Ehrlichia's DNA and Anaplasma's DNA was found in $64(43.84 \%)$ out of the 146 specimens (generated characteristic 524 bp products, Figure 2). Nested PCR detected ehrlichial DNA in both adult and nymph of Rhipicephalus sanguineus and Hyalomma asiaticum ticks in which $21.17 \%$ of nymphal and $53.42 \%$ of adult ticks were positive. Of 47 Rhipicephalus sanguineus from Meshkin-Shahr county, 30 (63.82\%) tested specimens were positive.

Out of the 30 infected specimens that were sequenced, $17(56.6 \%)$ specimens were infected with Anaplasma ovis, seven of these were Rhipicephalus sanguineus, six Hyalomma asiaticum, three Dermacentor marginatus and one Hyalomma anatolicum.

The Ehrlichia sp. infected ticks were $6(20 \%)$ out of 30 specimens, they were three Rhipicephalus sanguineus, two Dermacentor marginatus and one Hyalomma anatolicum.

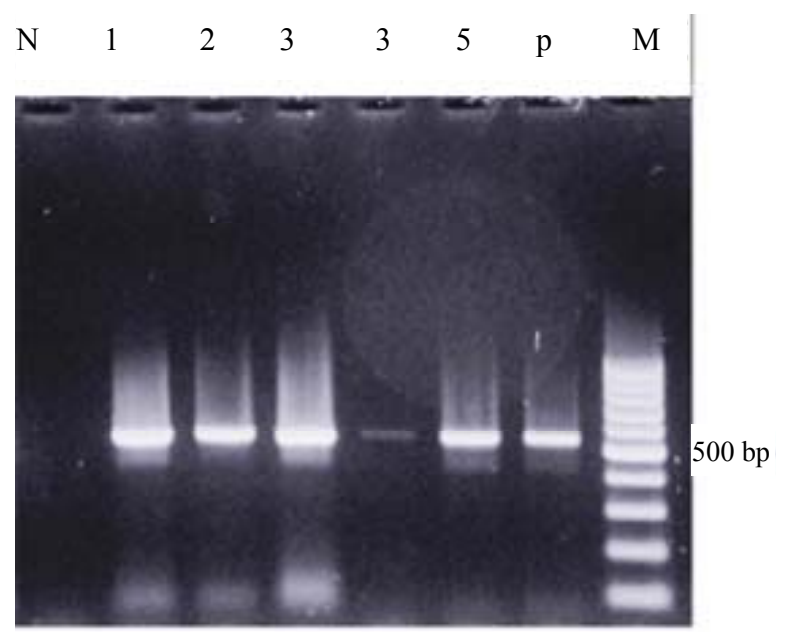

Figure 2. $16 \mathrm{~s}$ rRNA amplification of Ehrlichia spp. and Anaplasma spp. in ticks using nested-PCR. Lanes P: positive control, Lane N: Negative control, Lanes 1, 2, 3, 4, 5 represent Ehrlichia spp. and Anaplasma spp. (524 bp).

$5(16.66 \%)$ specimens were infected with Ehrlichia canis in which all of them were Rhipicephalus sanguineus.

Comparison of the sequences with available data in GenBank showed that the sequences were highly similar to ITS2 region of Anaplasma ovis and Ehrlichia sp., Ehrlichia canis with $99 \%, 97 \%$, and $99 \%$ identity respectively. Obtained sequences from this study were submited to the GenBank, under the accession numbers KC685627, KC685628 and KC685629.

\section{DISCUSSION}

Rhipicephalus sanguineus is believed to maintain Canine monocytic ehrlichiosis (CME) transstadially [4]. This species is widely spread not only in Iran but also in all over the world [9]. This research emphasizes that the most common tick on dogs is $R$. sanguineus as had been mentioned in 2011 by Mosallanejad et al. [18].

The results demonstrate the presence of E. canis in $R$. sanguineus as its vector. To our knowledge, this is the first report of E. canis in this tick from Iran; although, previously, E. canis had been detected in a variety of dogs ticks at Khouzistan province in Iran [13].

Nested PCR may enhance the sensitivity of detection of target nucleotide sequences [19]. This technique has been shown to be sensitive for direct identification of ehrlichiae in ticks [20,21]. Nested PCR with subsequent sequencing had been shown that hard ticks had been containing Anaplasma ovis and Ehrlichia spp. DNA [22]. This study provides primary data, regarding the prevalence of E. canis $(16.66 \%)$, in ticks from Ardebil in NorthWest of Iran.

The infection rate of $A$. ovis was $56.6 \%$ and seemed to be higher than A. phagocytophilum which was $5.1 \%$ in 
Bashirbod and his colleagues' study [12]; also it is higher than Anaplasma bovis infection rate in cattle, based on Noaman and Shayan research [23]. It was worth noting that there was no A. bovis and A. marginale in our study.

In addition, $21.17 \%$ of nymphs and at least $53.42 \%$ of adults were positive for A. ovis and Ehrlichia spp. Attempts to detect the agent in other tick species were also successful. This study has been intended to do a comprehensive survey of ehrlichia distribution in ticks; it was designed to investigate the presence of Anaplasma spp. and Ehrlichia spp. in north-west of Iran that has been shown Rhipicephalus sanguineus, R. bursa, Hyalomma asiaticum, $H$. anatolicum and $D$. marginatus can be infected with Anaplasma spp. and Ehrlichia spp.

It is proposed that the competency of vectors be measured in the future studies in Rhipicephalus sanguineus, Hyalomma asiaticum, H. anatolicum and Dermacentor marginatus.

\section{ACKNOWLAGEMENTS}

The authors wish to express their gratitude to Dr. Mohammad Barati PhD student at Department of Medical Parasitology, Tehran University of Medical Sciences and Mrs. Ramezani from Uromieh University of Medical Sciences. Also, I'd like to thank Dr. Ali-Asghar Bazdar for hiscollaboration. This study has been done by financial supports of Tehran University of Medical Sciences.

\section{REFERENCES}

[1] Munderloh, U.G., Jauron, S.D. and Kurtti, T.J. (2005) The tick: A different kind of host for human pathogens. In: Goodman, J., Dennis, D. and Sonenshine, D., Eds., Tickborne Diseases of Humans, ASM Press, Washington DC, 37-64.

[2] Perez, M., Bodor, M., Zhang, C., Xiong, Q. and Rikihisa, Y. (2006) Human infection with Ehrlichia canis accompanied by clinical signs in Venezuela. Annals of the New York Academy of Sciences, 1078, 110-117. doi:10.1196/annals.1374.016

[3] Dantas-Torres, F. (2008) The brown dog tick, Rhipicephalus sanguineus (Acari: Ixodidae): From taxonomy to control. Veterinary Parasitology, 152, 173-185. doi:10.1016/j.vetpar.2007.12.030

[4] Groves, M.G., Dennis, G.L., Amyx, H.L. and Huxsoll, D.L. (1975) Transmission of Ehrlichia canis to dogs by ticks (Rhipicephalus sanguineus). American Journal of Veterinary Research, 36, 937-940.

[5] Harrus, S., Bark, H. and Waner, T. (1997) Canine monocytic Ehrlichiosis: An update. Parasitology Research, 19, 431-442.

[6] Lord, C.C. (2008) Brown dog tick, Rhipicephalus sanguineus latreille (Arachnida: Acari: Ixodidae). Featured Creatures from Entomology and Nematology Department, Institute of Food and Agricultural Sciences, University of Florida, Gainesville, 1-5.

[7] Oyamada, M. (2005) Detection of Babesia canis rossi, B. canis vogeli, and Hepatozoon canis in dogs in a village of eastern Sudan by using a screening PCR and sequencing methodologies. Clinical and Diagnostic Laboratory Immunology, 12, 1343-1346.

[8] Kidd, L. and Breitschwerdt, E.B. (2003) Transmission times and prevention of tick-borne diseases in dogs. Compendium Small Animal/Exotics, 25, 742-751.

[9] Rahbari, S., Nabian, S. and Shayan, P. (2007) Primary report on distribution of tick fauna in Iran. Parasitology Research, 101, 175-177. doi:10.1007/s00436-007-0692-7

[10] Dantas-Torres, F. (2006) Rhipicephalus sanguineus (Acari: Ixodidae), the brown dog tick, parasitizing humans in Brazil. Revista da Sociedade Brasileira de Medicina Tropical, 39, 64-67. doi:10.1590/S0037-86822006000100012

[11] Estrada-Pena, A. (1999) Ticks feeding on humans: A review of records on human-biting Ixodoidea with special reference to pathogen transmission. Experimental and Applied Acarology, 23, 685-715. doi:10.1023/A:1006241108739

[12] Bashiribod, H., Kazemi, B., Eslami, G., Bigdeli, Sh., Bandehpour, M., Rahbarian, N. and Ramezani, Z. (2004) First molecular detection of Anaplasma phagocytophilum in Ixodes ricinus ticks in Iran. Journal of Medical Sciences, 4, 282-286. doi:10.3923/jms.2004.282.286

[13] Avizeh, R., Mosallanejad, B., Razi-Jalali, M.H. and Alborzi, A.R. (2010) Seroprevalence of Ehrlichia canis in dogs referred to Veterinary Hospital of Shahid Chamran University of Ahvaz, Iran. Archives of Razi Institute, 65, 21-26.

[14] Janbakhsh, B. (1957) A research review about ticks responsible for relapsing fever in Iran. Journal of Faculty of Health and Institute of Public Health and Research, 223-230.

[15] Walker, A.R., Bouattour, A., Camicas, J.L., Estrada-Pena, A., Horak, I.G., Latif, A., Pegram, R.G. and Preston, P.M. (2003) Ticks of domestic animals in Africa. A guide to identification of species. Bioscience Reports, Edinburgh Scotland, UK, 227.

[16] Fariai, J.L.M., Dagnone, A.S., Munhoz, T.D., João, C.F., Pereira, W.A.B., Machado, R.Z. and Tinucci-Costa, M. (2010) Ehrlichia canis morulae and DNA detection in whole blood and spleen aspiration samples. Revista Brasileira de Parasitologia Veterinária Jaboticabal, 19, 98102.

[17] Rar, V.A., Fomenko, N.V., Rudakova, S.A., Fedorov, E.G. Astanin, V.B. and Morozova, O.V. (2005) Tickborne pathogen detection, western Siberia, Russia. Emerging Infectious Diseases, 11, 1708-1715.

[18] Mosallanejad, B., RAlborzi, A. and Katvandi, N. (2012) A survey on ectoparasite infestations in companion dogs of Ahvaz district, south-west of Iran. Iranian Journal of Arthropod-Borne Diseases, 62-69.

[19] Haff, L.A. (1994) Improved quantitative PCR using nested primers. PCR Methods and Applications, 3, 332-337. doi:10.1101/gr.3.6.332

[20] Kramer, V.L., Randolph, M.P., Hui, L.T., Irwin, W.E., Gutierrez, A.G. and Vugia, D.J. (1999) Detection of the 
agents of human ehrlichioses in ixodid ticks from California. The American Journal of Tropical Medicine and Hygiene, 60, 62-65.

[21] Barlough, J.E., Madigan, J.E., Kramer, V.L., Clover, J.R., Hui, L.T., Webb, J.P. and Vredevoe, L.K. (1997) Herlichia phagocytophila genotype rickettsiae in ixodid ticks from California collected in 1995 and 1996. Journal of Clinical Microbiology, 35, 2018-2021.
[22] Cao, W.C., Gao, Y.M., Zhang, P.H., Zhang, X.T., Dai, Q.H., Dumler, J.S., Fang, L.Q. and Yang, H. (2000) Identification of Ehrlichia chaffeensis by nested PCR in ticks from southern China. Journal of Clinical Microbiology, 38, 2778-2780.

[23] Noaman, V. and Shayan, P. (2010) Molecular detection of Anaplasma bovis in cattle from central part of Iran. Veterinary Research Forum, 1, 117-122. 